\title{
STRATEGI BERBISNIS ONLINE DITENGAH PANDEMI CORONA VIRUS DISEASE 2019 COVID-19
}

\author{
Ahmad Maulana Irfanudin, Erlita Kurniawati, Jamaluddin, Ratih Andalusi, Noryani \\ Universitas Pamulang \\ Email:dosen01868@unpam.ac.id
}

\begin{abstract}
The purpose of Community Service Activities (PKM) is to carry out one of the three obligations of the Higher Education Tri Dharma. In addition, it is expected that by serving the community, the existence of higher education institutions can contribute to the development and application of knowledge to the community. The method of activity used is to visit the Al-Kamilah Foundation, having its address at Jalan Serua Raya, Bojong Sari, Depok to examine and find problems at the location so as to provide appropriate solutions to motivate the teaching staff and caregivers of the orphan and poor people. and the orphanage which is a small and medium business activist in the Bojongsari area of Depok, West Java and will provide training there on the 14th May 16, 2020. This training aims to improve the development of science and technology in Indonesia, which is expected to be able to develop business strategies using online or online media, especially during the Covid-19 pandemic for caregivers and teaching staff and generally for the orphans. The results of community service activities obtained show that prior to the implementation of the PKM, the caregivers and teaching staff as well as the orphans and the underprivileged were not yet familiar with marketing products online, also regarding the strategy of global business development, but after the implementation of the activity the participants were known. from the teaching staff as well as the orphans and poor children can understand the basics of business strategy, making advertising and marketing products simply. PKM activities play a positive role in increasing the knowledge and skills of participants. The knowledge gained in Community Service this time is expected to be able to provide enthusiasm especially for the lecturers and other academicians of the University of Pamulang in providing material counseling, motivation and contributing to the public in and outside the campus environment of the University of Pamulang
\end{abstract}

Keywords: Strategy, Online, Covid-19

Abstrak

Tujuan dari Kegiatan Pengabdian Kepada Masyarakat adalah untuk melaksanakan satu dari tiga kewajiban Tri Dharma Perguruan Tinggi. Selain itu diharapkan dengan pengabdian kepada masyarakat, keberadaan perguruan tinggi dapat memberikan kontribusi kepada pengembangan dan penerapan keilmuan kepada masyarakat. Metode kegiatan yang digunakan adalah dengan mengunjungi Yayasan Al-Kamilah, beralamat di Jalan Serua 
Raya, Bojong Sari, Depok untuk menelaah serta menemukan pemasalahan yang ada di lokasi tersebut sehingga dapat memberikan solusi yang tepat dalam memotivasi khususnya para tenaga pengajar dan pengasuh Yayasan yatim dan dhuafa serta panti yang merupakan pegiat usaha kecil dan menengah di wilayah bojongsari Depok Jawa Barat dan akan memberikan pelatihan disana pada tanggal 14 s.d. 16 Mei 2020. Pelatihan ini bertujuan agar dengan semakin berkembangnya IPTEK di Indonesia, diharapkan dapat mengembangkan Strategi berbisnis dengan menggunakan media Online atau daring terlebih di masa pandemi Covid-19 bagi para pengasuh serta tenaga pengajar dan umumnya bagi para adik-adik yatim piatu. Hasil kegiatan pengabdian masyarakat yang diperoleh menunjukkan bahwa sebelum pelaksanaan PKM, para pengasuh dan tenaga pengajar serta para yatim dan dhuafa belum mengenal pemasaran produk lewat media daring (online), juga mengenai strategi pengembangan bisnis secara global, tetapi setelah pelaksaan kegiatan diketahui para peserta yang terdiri dari tenaga pengajar serta adik-adik yatim piatu dan dhuafa dapat memahami dasardasar strategi berbisnis, membuat iklan dan pemasaran produk secara sederhana. Kegiatan PKM berperan positif dalam meningkatkan pengetahuan dan keterampilan peserta. Ilmu yang diperoleh pada Pengabdian Masyarakat kali ini diharapkan mampu memberikan semangat khususnya bagi para dosen maupun civitas akademika Universitas Pamulang lainnya dalam memberikan penyuluhan materi, motivasi serta berkontribusi bagi khalayak masyarakat di dalam maupun luar lingkungan kampus Universitas Pamulang.

Kata Kunci: Strategi, Daring, Covid-19

\section{A. PENDAHULUAN}

Covid-19 merupakan penyakit menular yang disebabkan oleh virus bernama SARSCOV-2, atau seringkali disebut Virus Corona. Virus Corona sendiri merupakan keluarga virus yang sangat besar. Ada yang menginveksi hewan, seperti kucing dan anjing, namun ada pula jenis Virus Corona yang menular ke manusia, seperti yang terjadi pada Covid-19. Covid-19 merupakan penyakit baru, jadi manusia belum punya kekebalan tubuh terhadap Virus SARS-Cov-2. Vaksin dan obatnya belum ditemukan. Saat ini, peneliti di penjuru dunia masih berlomba-lomba mencari vaksin dan obatnya.

Kurangnya sosialisasi dan tanggapnya pemerintah terhadap virus ini menyebabkan hampir di seluruh dunia terinfeksi virus Covid-19. Selain itu, masyarakat yang kurang sadar akan pentingnya menjaga kesehatan dan kebersihan Kurangnya sosialisasi Pedoman Pencegahan dan Pengendalian Covid-19 kepada masyarakat, sehingga banyak yang tidak mengetahui bahwa dirinya adalah Orang Dalam Pemantauan (ODP), Pasien dalam Pengawasan (PDP) dan Suspek dan mereka merasa sehat dan masih keluar kota dan keluar negeri, tanpa disadari sudah membawa virus Covid-19. Masih banyak juga masyarakat yang tidak mentaati peraturan pemerintah untuk di rumah saja menjadi bagian penyebab kenaikan penularan yang terjadi hampir di 200 negara.

Hal tersebut menyebabkan kenaikan kasus yang terinfeksi Covid-19 hampir 200 negara di Dunia. Dari 193 negara yang terinfeksi Covid-19 per tanggal 29 April 2020 sebanyak 
3.128.995 orang, sembuh 953.321 orang dan meninggal 217.094. Data yang diperoleh dari Worldometers pada Rabu 29 April 2020 jumlah yang terinfeksi di Indonesia terus meningkat dengan total 9.771 kasus positive, dirawat sebanyak 7.596 orang, meninggal 784 dan sembuh sebanyak 1.391 orang. Dari jumlah tersebut Provinsi DKI Jakarta paling tinggi yang terinfeksi sebanyak 4092 orang dengan data 370 orang meninggal dan sembuh 440 orang.

Hal ini menyebabkan banyak Pemimpin Pemerintah Daerah yang melakukan Lockdown di daerahnya masing-masing untuk mengurangi penularan virus tersebut. Oleh karena itu, Pemerintah Daerah mengajukan Pembatasan Sosial Berskala Besar (PSBB) yang diajukan kepada Menteri Kesehatan yang diatur dalam Undang-Undang No. 6 Tahun 2018 tentang Karantina Kesehatan dan sesuai dengan Keputusan Presiden Republik Indonesia Nomor 11 Tahun 2020 tentang Penetapan Kedaruratan Kesehatan Masyarakat Corona Virus Desease 2019 (Covid-19).

Penyebaran Covid-19 yang bersifat luar biasa dengan ditandai jumlah kasus dan/atau jumlah kematian telah meningkat dan meluas lintas wilayah dan lintas negara dan berdampak pada aspek politik, ekonomi, sosial, budaya, pertahanan dan keamanan, serta kesejahteraan masyarakat di Indonesia, maka Presiden mengeluarkan Peraturan Pemerintah Republik Indonesia Nomor 21 Tahun 2020, tentang Pembatasan Sosial Berskala Besar Dalam Rangka Percepatan Penanganan Corona Virus Disease 2019 (Covid-19).

Dalam kegiatan Pengabdian Kepada Masyarakat kami melakukan kerjasama dengan Yayasan Yatim dan Dhu'afa Panti Asuhan Al-Kamilah didaerah Serua Bojong Sari DepokJawa Barat. Berdasarkan peraturan pemerintah Pusat dan Pemerintah Daerah Jawa Barat dikarenakan adanya Pandemi Covid-19 warga dilarang keluar rumah. Hal ini dilakukan untuk mencegah penyebaran Covid-19 di daerah sekitarnya. Jawa Barat merupakan provinsi yang semakin naik kasus Pandemi ini, sehingga dikeluarkannya Peraturan Daerah mengenai Pembatasan Sosial Berskala Besar (PSBB).

Hal ini sangat berdampak untuk warga yang kesehariannya sebagai Staff, pengajar, pedagang, pelayanan yang penghasilannya didapatkan dengan cara bertemu langsung dengan para konsumen atau kliennya. Dari hasil survey dan wawancara melalui Yayasan Yatim dan Dhu'afa Panti Asuhan Al-Kamilah bahwa permasalahan yang ada sekarang ini dan masih berlanjut salah satunya yaitu Tenaga pengajar atau guru yang didaerah Serua Bojong Sari Depok-Jawa Barat tidak mendapatkan penghasilan, dikarenakan tidak bisa keluar rumah untuk memberikan ilmunya secara langsung kepada murid-muridnya. Kemendikbud menyarankan untuk memberikan pembelajaran secara online/daring, hal ini tidak bisa dilakukan oleh guru ngaji dan murid yang tidak memiliki alat komunikasi yang bisa mendukung pembejalaran tersebut. Selain itu, mereka juga tidak memiliki kuota yang besar untuk melakukan zoom atau webex yang dilakukan oleh sekolah-sekolah swasta lainnya.

\section{B. METODE PELAKSANAAN KEGIATAN}

Metode kegiatan yang digunakan adalah dengan mengunjungi Yayasan Al-Kamilah, beralamat di Jalan Serua Raya, Bojong Sari, Depok dan mencari pemasalahan yang ada di tempat tersebut sehingga dapat memberikan solusi yang tepat dalam memotivasi anggota yang dituntut untuk beradaptasi dalam kegiatan bisnis di Depok Jawa Barat khususnya para anggota dan pengasuh Yayasan Al-Kamilah, beralamat di Jalan Serua Raya, Bojong Sari, Depok, dan memberikan pelatihan disana pada tanggal 14 s.d. 16 Mei 2020. Pelatihan ini bertujuan agar para anggota Yayasan Al-Kamilah, agar dapat menyusun strategi berbisnis serta meningkatkan kualitas diri melalui transfer ilmu teori sekaligus praktik ini. 
Sebelum dilaksanakannya kegiatan pengabdian kepada masyarakat di Yayasan AlKamilah, beralamat di Jalan Serua Raya, Bojong Sari, Depok, anggota tim yang berjumlah 5 orang dosen melakukan beberapa tahapan, melalui pra survei ke lokasi untuk berkoordinasi dengan Kepala Yayasan Al-Kamilah, Bp. Ust Badruddin. Serta perijinan melaksanakan acara pengabdian, selanjutnya tim membuat penjadwalan kegiatan selama 3 (tiga) hari dengan berkoordinasi termasuk pembuatan materi untuk dapat disampaikan serta diaplikasikan oleh para anggota forum, sampai dengan pembuatan laporan kegiatan pengabdian kepada masyarakat dan pengajuan keluaran dari kegiatan pengabdian masyarkat berupa jurnal PKM..

Berikut ini adalah tahapan pelatihan yang dilakukan:

1. Tahap persiapan, Tahap persiapan yang dilakukan meliputi:

a. Survey awal,

b. Pemantapan dan penentuan lokasi dan sasaran. Setelah survey maka ditentukan lokasi pelaksanaan dan sasaran peserta kegiatan.

2. Tahap Pelaksanaan Pengabdian Kepada Masyarakat

Tahap ini akan diberikan penjelasan mengenai pengenalan dan metode berbisnis melalui media daring, selanjutnya mengenai bagaimana cara menyusun strategi berbisnis dengan daring.

3. Tahap Pelatihan

Untuk melaksanakan kegiatan tersebut digunakan beberapa metode pelatihan yaitu:

a. Metode ceramah

b. Metode tanya jawab

Metode simulasi

Program Pengabdian Kepada Masyarakat yang akan kami lakukan di Yayasan AlKamilah, Bojong Sari, Depok dengan objek penelitian yaitu para anggota termasuk didalamnya Pembina dan tenaga pengajar serta adik-adik yatim piatu dan dhuafa Yayasan Al-Kamilah adalah.

1. Pemberian materi penggunaan digital Marketing dalam menghadapi pandemi Covid-19 kepada staff, guru di sekitar Yayasan Al-Kamilah agar dapat menggiatkan UKM dan menambah penghasilan di masa pandemi.

2. Memberikan bantuan berupa pangan (sembako) dan masker untuk para Staff, Guru dan murid di sekitar Yayasan Al-Kamilah.

\section{HASIL DAN PEMBAHASAN}

\section{Tahap Persiapan}

Sebelum melaksanakan Pengabdian Kepada Masyarakat kami selaku Dosen Universitas Pamulang melakukan peninjauan lokasi pelaksanaan PKM. Berdasarkan data dan informasi yang kami dapatkan bahwa akibat dari pandemic COVID 19 ini di Yayasan Yatim dan Dhu'afa Panti Asuhan Al-Kamilah mengalami kesulitan untuk memenuhi kebutuhan mereka sehari-hari. Dimana terdapat beberapa usaha yang mereka lakukan untuk memenuhi kebutuhan hidup mereka harus berhenti secara total.

Pada tahap ini Dosen Universitas Pamulang bekerjasama dengan Yatim dan Dhu'afa Panti Asuhan Al-Kamilah bekerjasama untuk melaksanakan PKM (Pengabdian Kepada Masyarakat) dengan melakukan penandatanganan Kerja Sama (PKS) dengan nomor 0086/D5/SPKPM/LPPM/UNPAM/X/2020 pada tanggal 12 Mei 2020, Di saksikan oleh perwakilan Dosen Universitas Pamulang dan Pengurus yayasan Yatim dan Dhu'afa Panti Asuhan Al-Kamilah.

Setelah itu, TIM PKM yang terdiri dari lima orang Dosen UNPAM melakukan Forum Group Discussion (FGD) untuk mempersiapkan pelaksanaan Pengabdian Kepada Masyarakat 
(PKM) untuk tanggal 14-16 Mei 2020 Juni 2020 via nnline dengan menggunakan applikasi zoom.

\section{Tahap Pelaksanaan Pengabdian Kepada Masyarakat}

Pelaksanaan Pengabdian Kepada Masyarakat di yayasan Yatim dan Dhu'afa Panti Asuhan Al-Kamilah Sawangan- Depok pada tanggal 14-16 Mei 2020.

Kegiatan ini terlaksana atas kerjasama Universitas Pamulang dengan Yayasan Yatim dan Dhu'afa Panti Asuhan Al-Kamilah dengan tema "Strategi Berbisnis Online ditengah Pandemi Corona Virus Disease 2019 COVID-19". Peserta pelatihan diikuti oleh seluruh penghuni Yayasan Yatim dan Dhu'afa Panti Asuhan Al-Kamilah, yang kebanyakan masih berusia 12-16 tahun, lalu para pengurus yayasan dan warga sekitar lokasi.

Kegiatan ini di ketua oleh Jamaluddin, S.E., M.M. dengan narasumber Ibu Ratih Andalusi S.SI.,MM, Erlita Kurniawaty, SE, M.M, Ahmad Maulana Irfanudin, S.Kom, M.M dan Noryani, S.E.,M.M. Karena pemerintah melakukan pembatasan sosial dengan penerapan Pembatasan Sosial Berskala Besar (PSBB), jadi pelaksanaan kegiatan dibagi menjadi 2, yaitu kegiatan langsung dan tidak langsung.

\section{Tahap Pelatihan}

Untuk melaksanakan kegiatan tersebut digunakan beberapa metode pelatihan yaitu:

a. Metode ceramah

Metode yang digunakan dalam pelatihan bisnis online dimulai dengan memberikan ceramah atau presentasi dengan tema "STRATEGI BERBISNIS ONLINE DITENGAH PANDEMI CORONA VIRUS DISEASE 2019 COVID-19”, dengan narasumber Bapak Yusep Prihanto yang dibantu oleh Ibu Ratnawati sebagai moderator.

b. Metode tanya jawab

Setelah sesi ceramah sudah selesai, maka dilanjutkan dengan sesi tanya jawab. Hasilnya, peserta sangat antusias untuk menanyakan perihal bagaimana strategi bisnis dalam praktiknya bisa berjalan dengan baik. Peserta yang bertanya kami berikan cinderamata dari Universitas Pamulang dan sumbangsih dari dosen-dosen UNPAM.

c. Metode simulasi

Pelatihan ini juga diberikan metode simulasi, sehingga peserta langsung dapat mempraktekan apa yang sudah disampaikan. Apabila ada kendala maka langsung dibantu pada saat pelaksanaan PKM. Simulasi penting dilakukan untuk mengetahui seberapa besar tingkat pengetahuan dan ilmu yang diserap pada saat pelatihan.

\section{KESIMPULAN DAN SARAN}

\section{Simpulan}

Kegiatan Pengabdian Kepada Masyarakat oleh Lembaga Penelitian dan Pengabdian Masyarakat (LPPM) Universitas Pamulang yang dilakukan oleh dosen-dosen program studi Manajemen telah berjalan dengan lancar dan mendapat sambutan hangat dari tempat pelaksanaan kegiatan ini yaitu Yatim dan Dhu'afa Panti Asuhan Al-Kamilah. Diharapkan ilmu yang disampaikan tentang strategi berbisnis online yang di berikan bermanfaat dan dapat menyelesaikan permasalahan yang terjadi.

Dalam laporan kegiatan ini mungkin banyak kekurangan yang ada, untuk itu kami berharap masukan dan kritikan dalam rangka perbaikan untuk kegiatan-kegiatan pengabdian masyarakat di masa yang akan datang. Semoga kegiatan pengabdian masyarakat ini dapat bermanfaat bagi masyarakat sekitar lingkungan Universitas Pamulang dan lainnya. 
Akhirnya, kami mengucapkan terima kasih kepada seluruh pihak yang telah mendukung kegiatan yang kami laksanakan dan kami mohon maaf apabila dalam laporan ini banyak ditemukan kekurangan.

\section{Saran}

Berdasarkan hasil kegiatan Pengabdian Kepada Masyarakat, maka kami dari Tim Dosen Universitas Pamulang memberikan saran diantaranya sebagai berikut:

1. Karena ilmu berbisnis masih cukup luas, kegiatan ini baiknya tidak hanya dilaksanakan satu kali saja, diharapkan ada kegiatan lainnya, agar para peserta pelatihan dari Yatim dan Dhu'afa Panti Asuhan Al-Kamilah memahami secara menyeluruh.

2. Fasilitas yang digunakan oleh Dosen Dosen UNPAM yang melakukan pelatihan sangat sederhana, diharapkan dari pihak kampus, meberikan fasilitas agar proses pembelajaran lebih effektif.

\section{Ucapan Terima Kasih}

Rasa syukur dan suka cita kamu haturkan kepada segenap pihak yang telah mensukseskan kegiatan PKM dengan judul "STRATEGI BERBISNIS ONLINE DITENGAH PANDEMI CORONA VIRUS DISEASE 2019 COVID-19” kepada:

1. Rektor Dr. H. Dayat Hidayat, M.M, Rektor Universitas Pamulang Tangerang Selatan Banten.

2. Dr. Ali Maddinsyah, S.E., M.M., selaku Ketua LPPM Universitas Pamulang Tangerang Selatan - Banten.

3. Dr. Kasmad, S.E., M.,M., selaku Ketua Program Studi Manajemen Universitas Pamulang Tangerang Selatan - Banten.

4. Dr. Udin Ahidin, S.E., M.M., C.M.A, Selaku Wakil Program Studi Manajemen Universitas Pamulang Tangerang Selatan - Banten.

5. Drs. Waluyo Jati, M.M., Selaku Sekretaris Program Studi Manajemen Universitas Pamulang Tangerang Selatan - Banten.

6. Ust Badruddin., selaku Ketua Yayasan dan Panti Asuhan Al-Kamilah, Bojongsari, Depok

7. Mahasiswa Universitas Pamulang yang juga ikut berkontribusi terhadap kelancaran kegiatan PKM.

\section{DAFTAR PUSTAKA}

Berry, A. R. (2001). Small and Medium Enterprises Dynamics in Indonesia. Bulletin of Indonesian Economic Studies, 363-384.

Fadiati, A., \& Purwana, D. (2011). Menjadi Wirausaha Sukses. Bandung: PT Remaja Rosdakarya.

Jauhari, J. (2010). Upaya Pengembangan Usaha Kecil dan Menengah (UKM) dengan Memanfaatkan E-Commerce. Jurnal Sistem Informasi (JSI), Vol. 2., No. 1, 159-168.

jurnal.id. (2019, Maret 12). Retrieved from https://www.jurnal.id:

https://www.jurnal.id/id/blog/strategi-bisnis-untuk-bersaing-di-era-digital/

Kasali, R., \& dkk. (2010). Modul Kewirausahaan. Jakarta: HIkmah (PT Mizan Publika).

Ling, A. (2013). Pengelolaan dan Pengembangan Usaha pada Usaha Mikro Kecil Menengah (Studi Deksriptif pada Rumah Makan Palem Asri Surabaya). AGORA Vol. 1., No. 1, 18 . 